FACTA UNIVERSITATIS

Series: Physical Education and Sport, Vol. 16, No 3, 2018, pp. 595 - 610

https://doi.org/10.22190/FUPES180616054M

Narrative review article

\title{
POSSIBLE MODELS OF INTEGRATION OF PRESCHOOL MATHEMATICS AND PHYSICAL EDUCATION
}

\author{
UDC 796.015:510.2-053.5 \\ 796.015:159.922
}

\section{Nela Malinović-Jovanović, Milica Ristić}

Pedagogical Faculty in Vranje, University of Niš, Vranje, Serbia

\begin{abstract}
The main goal of this paper is to suggest possible models of integration of preschool mathematics and physical education (PE) in accordance with the characteristics of children's cognitive development in this period, goals and objectives of preschool education and specifics of these subject areas in working with preschool children. The object of the investigation was "why it is necessary to integrate teaching content of these specific subjects", the different integration models, similar goals and learning objectives were specified, as well as appropriate types of integration suitable for linking the content of these subjects. Through the complete integration of related goals, as well as by observing mathematics through PE, and PE through mathematics, various possibilities of integrating teaching materials of these subjects are presented through specific examples as well as the appropriate instructions for their design. Integration of these subject areas is useful because due to the abstract nature of mathematical concepts, PE allows children to learn about, explore and use to apply key mathematical concepts and language from another angle.
\end{abstract}

Key words: preschool mathematics education, preschool physical education, characteristics of cognitive development, integration, models of integration

\section{INTRODUCTION}

The primary goal of preschool education is to contribute to the overall development of a preschool age child, in the sense that it should provide children with the conditions and stimulus to develop their abilities and personality traits, to expand their experience and build knowledge about themselves, other people and the world. At the same time, different aspects of child's knowledge, action and development overlap and are mutually conditioned (Preschool Curriculum Framework, 2006, 49).

Received June 16, 2018 / Accepted January 04, 2019

Corresponding author: Nela Malinović-Jovanović

University of Niš, Faculty of Pedagogy, Partizanska 14, 17500 Vranje, Serbia

Phone: +381 17421633 •E-mail: nelamj@ucfak.ni.ac.rs 
Physical education (PE) is a field that advocates a holistic approach to human development. This approach emphasizes that the mind and the body are one entity, and that anything that happens to the one will affect the other. Physical educators therefore believe that the "whole child" comes to school to be educated and that this requires both mental and physical training (Sibley \& Etnier, 2003, 243).

Teachers are expected to be experts both in the subject they teach and in the field of teaching in general. In order to accomplish this, they have to continually improve their own knowledge and reflect on their own practice (Momčilović \& Momčilović, 2016). The moment teachers start reflecting on their own teaching practice, they become reflective practitioners (Maksimović \& Osmanović, 2018).

Preschool age is a period rich in developmental potentials. It is a period when many cognitive abilities develop - the development of intellectual abilities in this period can be crucial for the later progress of children in school. It is also important for the development of motor and perceptual skills because preschool children have a great need for movement, are vigorous and eager for physical activity, their physical development is distinguished by elasticity, speed and endurance. The possibility of using mathematics learning content to stimulate the development of a preschool child stems from the educational system goals, because nowadays the importance of developing mental structures that are at the core of mathematical thinking is specifically emphasized. That is why the preschool period is very important for mathematical education, both for the process of further mathematics education, and for the overall child's cognitive development (Maričić, Stakić, \& MalinovićJovanović, 2018, 631). Numerous researchers confirm this fact and point out that preschool mathematics education is the basis for later mathematics' improvement at school (Claessens, Duncan, \& Engel, 2009; Krajewski \& Schneider, 2009) and that kindergarten mathematical knowledge is the most important set of skills for later achievement (Claessens et al., 2009). Therefore, the development of preschool children should be directed so as to create all the prerequisite for successful contemporary mathematics education and to find ways to achieve these goals. Thus, the guidelines for the development of initial mathematical concepts in preschool children suggest the development of skills of understanding quantitative relationships and the nature of learning in preschool children.

The learning process of preschool children is specific and differs from the learning process of school age children and adults. Modern research on learning and development suggests that it is more difficult for children of a preschool age to learn if the subject areas are isolated (Ćebić, 2009, 15). The general principles of the preschool curriculum envisage that preschool teaching is carried out according to Model A or Model B, and preschools themselves decide which of these two models will be used as the basis for planning the activities. Model $A$ insists on integrating mathematics with other areas of knowledge, that is, it claims that mathematical concepts should not be adopted as an isolated content area, and that all influences, actions, acts and interactions that lead to the development of physical, logical and mathematical knowledge should be included (Preschool Curriculum Framework, 2006, 125). When planning and designing the curriculum and teaching process according to Model B, it is recommended that content areas be thematically connected and intertwined in order to develop a comprehensive understanding of the reality the child is a part of, that is, to link children's personal experience acquired outside the preschool with all kinds of knowledge he/she acquires in it (Preschool Curriculum Framework, 2006, 143). Similarly, the recommendations of the National Association for the Education of Young Children (NAEYC) and the National Council of Teachers of Mathematics (NCTM) are 
directed to "integrate mathematics with other activities and other activities with mathematics" (NAEYC \& NCTM, 2002, 7).

Cvejić \& Buišić (2012) and Grube \& Beaudet (2005) claim that the integration of PE with other subject areas is something that must inevitably be considered. According to Cvejić and Buišić (2012), integration can and must be conducted not only directly, by expanding the activities, but also indirectly by integrating theoretical goals of PE (the message) in other subject areas (the promotion of physical activity). Therefore, since learning at this age must not be limited only to the intellectual sphere of personality, but it is also necessary to engage all aspects of its development (physical sphere and emotions, as much as children's mental skills) (Kamenov, 1987, 28), while taking into account the fact that both models insist on content linking (both within subject areas and among them), we believe that research into the possibilities of integrating mathematics and PE is important for the education process of preschool age children.

This paper explores the different models of integration, and it designs new ones in accordance with the goals and tasks of preschool education, the characteristics of preschool children and the specifics of mathematics and PE in working with children of a preschool age.

\section{PRESCHOOL CHILDREN'S COGNITIVE DEVELOPMENT AND THE DEVELOPMENT OF MATHEMATICAL CONCEPTS}

Lee \& Ginsburg (2009) state that one of the most commonly held misconceptions by teachers about early mathematics education is that Young children are not ready for mathematics education, by which they underestimate children's mathematical abilities in their early years (p. 37). The authors believe that the root cause can be found in their interpretation of Piaget's theory, which they believe focuses on what children cannot do, that is, that children are still insufficiently cognitively mature and unable to understand abstract concepts or the logical thinking required in mathematics.

Mathematical concepts truly are abstract concepts, that is, concepts that are free from all properties of material reality, excluding the properties of spatial form and quantitative relationships. Therefore, when talking about mathematical concepts, we have in mind the term that contains certain general properties in the field of quantitative relations and spatial forms, while other properties of reality are ignored (Malinović \& Milojević, 2013, 176). According to Jean Piaget's theory of cognitive development, this would mean that in order to adopt mathematical concepts, it is necessary for thinking to reach the cognitive stage of formal operations.

According to Piaget \& Inhelder (1978), even though the mental classification of objects begins around four years of age which is considered the beginning of the formation of the classification operation, intuitive thinking is still dominated by perceptive experiences. Based on his research, Piaget described and explained a number of characteristics specific to children's thinking in the preoperational stage of cognitive development. At this stage, children's reasoning is pre-logical, and this deficiency is compensated with intuition. Their opinions are created and based on information obtained from observation - moreover, children judge every moment or every process isolated from the rest. All in all, intuitive thinking remains preoperational because it lacks an integrated system of coordinated mental operations. 
For example, at a preoperative stage, a child can know how to count, but that does not mean that he or she is familiar with the concept of number. The concept of number (not just the notion, names of numbers, or simple reciting of numbers) is a synthesis of classification operations (class inclusions) and seriation. It implies an abstraction of qualities that make each specific element equal to another element $(1=1=1=1)$. After this is established, the class-inclusion of these elements is done $(1<1+1<1+1+1$ or $1<2<3)$. (Piaget $\&$ Inhelder, 1978; Piaget \& Inhelder, 1990). The question that arises is how to bring children of preschool age closer to such abstract contents that largely belong to the stage of preoperational intuitive thinking?

According to Lee \& Ginsburg (2009), in the last few decades, many researchers have focused their attention on what children can do and found many proofs that support the fact that children are much more competent and have a wider range of mathematical abilities than Piaget's theory might lead one to believe. The authors quoted Vygotsky (1978) who claimed that: Children's learning begins long before they enter school... They have had to deal with operations of division, addition, subtraction, and the determination of size. Consequently, children have their own preschool arithmetic, which only myopic psychologists could ignore (p. 84). Lee \& Ginsburg (2009) conclude that those who teach and educate children must not overlook these impressive informal mathematical strengths of children in the early years. Young children are ready and eager to learn stimulating and challenging mathematics, and their mathematical learning is not limited to the concrete; it is often abstract.

\section{Is it Possible to InTEGRATE PHySiCAL EDUCATION AND MATHEMATICS?}

With differing goals for each subject area, it could seem like a challenge to create learning experiences that support both areas. The question then becomes, why do it?

Clements \& Sarama (2018) investigated one of the myths about mathematics learning which says that Young Children Must Sit Down and Learn Math - learning mathematics usually involves sitting with a book and writing homework (p. 2). Contrary to this claim, and especially in young children, learning mathematics is linked to engagement and interest. High-quality early mathematics... is about building with unit block sand estimating and checking how many steps it is to the playground. It involves playing games, counting the dots on dice, and moving a game piece that many spaces (Clements \& Sarama, 2007/2013; Ginsburg, Greenes, \& Balfanz, 2003; Griffin, Clements, \& Sarama, 2007). Observations of preschoolers show that when they play, they engage in mathematical thinking at least once in almost half of each minute of play. Almost 9/10 of children engage in at least one or more math activities during play episodes (Seo \& Ginsburg, 2004).

It is widely known that the preschool period is extremely important for the development of motor and perceptual functions, and their development in this period is of great importance. The ability to learn movement competence creates the essential nerve cell networks which are the very essence of the learning process. However, many early year practitioners are reporting that more children appear to be entering nurseries and schools without the physical skills for large motor and fine motor play (Do and discover, fun activities to develop physical skills in the early years, 2008, 3). Piaget himself also said that skills and relationships learned during physical activity carry over to the learning of other relationships and concepts. This would suggest that it is the movement involved in activity that is important, rather than the actual physical exertion. 
The large majority of research in this field found a positive association between children's physical activity participation and academic achievement. For instance, the conclusion that some intervention and longitudinal studies was that physical activity intervention leads to significant improvements in children's math scores (Gao, Hannan, Xiang, Stodden, \& Valdez, 2013; Hollar et al., 2010; Riley, Lubans, Morgan, \& Young, 2014; Stevens, To, Stevenson, \& Lochbaum, 2008) and motor skills (Ericsson \& Karlsson, 2014).

Numerous mechanisms have been proposed to explain the relationship between physical activity and cognition. These mechanisms can be categorized into two broad categories: physiological mechanisms and learning/developmental mechanisms. The physiological mechanisms (for instance increased cerebral blood flow, alterations in brain neurotransmitters, structural changes in the central nervous system) are based on physical changes in the body brought about by exercise. The learning/developmental mechanisms state that movement and physical activity provide experiences that aid, and may even be necessary for, proper cognitive development. Educators have suggested that movement stimulates cognitive development in very young children (Sibley, \& Etnier, 2003).

Due to the abstract nature of some concepts in mathematics, many children find learning in this subject difficult. Being able to visualise shape, space, distance and volume and then apply these concepts in practical situations can support understanding. Many teachers approach the following mathematical concepts through physical exploration: length, distance, area, mass, angle, time, space, analysis and problem solving. Children need to explore these concepts regularly and practically in order to reinforce learning. For example, we can consider the following: A PE lesson focusing on exploring the dynamics of balance. The children investigate using different bases of support to see what provides them with more balance or less stability. How could you use this learning activity to develop the children's understanding of area and shape in the context of providing a stable or unstable base? One illustration is the meaning and use of data. How can data can be collected, analysed, processed and operationalised within a mathematical arena? Such examples can include timetabling of sporting events, scoring of activities, comparisons of team results through the use of league tables (how many goals scored for and against; what is the total number of points scored?) as well as identifying trends and patterns in any of the data that has been collected. It is also a valuable way to illustrate to children that learning can be taken beyond the classroom and into a physical context where the context promotes an atmosphere of enquiry (Haydn-Davies, Kaitell, Randall, \& Shaughnessy, 2014).

In order to be able to speak at all about the successful integration of mathematics and $\mathrm{PE}$, it is necessary to identify and single out the related learning objectives of these subject areas and to choose the appropriate model of integration which would respect both the characteristics of thinking of preschool children, as well as the specifics of these subject areas in working with children of a preschool age.

\section{MODELS OF INTEGRATION OF MATHEMATICS AND PHYSICAL EDUCATION}

Integration represents drawing together of the natural connections among various curriculum areas to assist children in making sense of their world. It assists learners in acquiring the skills, attitudes, and knowledge that will allow them to grow and learn in a holistic manner and provides educators with opportunities to organize and choose teaching strategies. This integrates learning experiences, which build on the child's level of 
development and strengthens and extends their base for future learning (Kindergarten integrated curriculum document, 2008, 36).

"The integration has its basis in learning theorists who advocate a constructivist view of learning. There is a body of brain research that supports the notion that learning is best accomplished when information is presented in meaningful, connected patterns. This includes interdisciplinary studies that link multiple curricular areas" (Lake, 1994, 193).

A basic definition is offered by Humphreys (Humphreys, Post, \& Ellis, 1981) when he stated, "An integrated study is one in which children broadly explore knowledge in various subjects related to certain aspects of their environment" (p. 11).

There are various views and models which deal with the integration. Some of them have been designed for specific subject areas and mainly relate to the integration of mathematics and natural sciences in elementary and high schools, as well as at faculties, while some are universal and can be applied to all subject areas.

Several authors have gone beyond a single definition of integration to a continuum of integration. Fogarty and Stoehr's (2008) ten views for integration are the most frequently used planning models in the field. They define different types of integration examples and are grouped into three types: within a single discipline, across several disciplines and within and across learners. Integration "begins with an exploration within single disciplines (the fragmented, connected, and nested models), and continues with models that integrate across several disciplines (the sequenced, shared, webbed, threaded, and integrated models), continuum ends with models that operate within learners themselves (the immersed model) and finally across networks of learners (the network model)“ (Fogarty, 1991, 61). Jacobs (1989) proposed several ways in which integration can be done. The continuum of options for content design are: discipline-based, parallel disciplines, multi-disciplinary, interdisciplinary units/courses, integrated day and a complete program. Each option was considered in terms of its characteristics, advantages and disadvantages, and examples of existing applications of the continuum.

Based on the results of numerous studies Kiray (2012) developed the balance model for the integration of mathematics and natural sciences where the continuum is replaced with balance which is achieved by giving an equal share of time to both disciplines in the process: Mathematics; Math - Centered, Science - Assisted Integration; Math - Intensive, Science - Connected Integration; Total integration; Science - Intensive, Math - Connected Integration; Science - Centered, Math - Assisted Integration; Science.

Kukušin (2004) identifies the following types of integration: the integration of contents related to the same education field, where the contents can be paid equal attention to or are the basis is one subject area; integration of related contents from different subject areas, whereby all are given equal attention; integration of contents of related teaching areas, where one is the main one and the others serve as an illustration; integration of contents of not so related learning areas and integration of general education contents starting from the specifics of the educational institution (in Vilotijević \& Vilotijević, 2008, 147).

Haydn-Davies et al. (2014) have developed a model of integration of mathematics and PE in younger primary school grades that includes the following: Learning about mathematics through PE, Learning about PE through mathematics, Learning through mathematics and PE, and Broader learning in mathematics and PE.

Some of the models, which are, among other things, intended for use in preschool education are as follows: The EASY Minds programme involves the integration of PA within 
mathematics for Stage 3 children (ages 10-12) (Riley et al., 2014); C4L (Connect4Learning) based on a Curriculum Research Framework (Sarama, Brenneman, \& Clements, 2017).

When designing the model of integration of early mathematics and PE, we paid attention to respecting subject specific knowledge, skills and understanding while at the same time recognising and valuing the contributions between the different subjects. In this way, the following types of integration have been designed:

Total Integration of Related Learning Objectives (TIRLO),

In total integration, the target is to devote an equal share of the PE and mathematics objectives. Neither of the subject areas is regarded as the (main) core of the curriculum. Since these are related objectives, they are not identified as separate physical or mathematics objectives but are integrated into the system of objectives and tasks. One of the aims of the total integration of related learning objectives is to help children to acquire the outcomes of PE as well as the initial mathematics concepts.

Total Integration of Unrelated Learning Objectives (TIULO),

In this integration, objectives are different, but at the same time they are achieved in such a way that equal attention is paid to the contents of both subject areas to which they relate. The aim of this type of integration is the full acquisition of the mathematical and physical outcomes at the end of the teaching-learning process. It is applied when knowledge is acquired from both subject areas at the same time by designing activities to find links between contents that at first glance do not aim for the same goal, but can be implemented together in both subject areas so that children simultaneously acquire knowledge related to them.

Mathematics - Centred, Physical - Assisted Integration (MCPAI)

In this approach, mathematical objectives are basic, and PE is regarded as a supportive discipline. The integration of PE and mathematics can be achieved through the organisation of physical and mathematical topics (priority and secondary topics) so as to make it possible for children to transfer (link) these topics themselves. This type of integration is suitable for activities where knowledge about mathematical content is acquired, and skills and habits are developed, that is, PE content is practiced. PE content can be used to provide examples of where mathematical concepts are applied to PE content in real life precisely due to the fact that PE provides a range of opportunities for mathematical learning.

Physical - Centred, Mathematics - Assisted Integration (PCMAI)

In this approach physical objectives are basic, and mathematics is regarded as a supportive discipline. The integration of PE and mathematics can be achieved through the organisation of physical and mathematical topics so as to make it possible for children to transfer (link) these topics themselves. This type of integration is suitable for activities that help acquire knowledge about the PE content and develop skills and habits about mathematical concepts.

\section{IDENTIFY RELATED LEARNING OBJECTIVES}

The first step when identifying related learning objectives was to analyse the models provided in the Preschool Curriculum Framework from the aspect of the possibility of connecting the goals and objectives of mathematics and PE. Based on this, from the 
existing models of working with preschool children, the one that will serve as the basis for integration was chosen.

The Preschool Curriculum Framework specifies general goals and specific learning objectives which should be achieved through teaching. On the one hand, the specified goals and objectives are related to the achievements - developmental outcomes or built-in knowledge, and, on the other hand, they are related to actions and interactions leading to the development of knowledge and developmental achievements. They are expressed in terms of child behaviour (ability and skill to do something), knowledge of certain facts (knowledge about things) or personality traits and personal attitudes, such as creativity, initiative, etc. (Preschool Curriculum Framework, 2006, 30).

Model $A$ is seen as an open education system that requires an institution, educator and child to arbitrarily design activities in the kindergarten. It formulates the overall goals that are to be achieved by the education of children related to all subject areas, and then the recommended content for each of these subject areas are suggested. Specific objectives which are related to each subject area and more closely define it are not given in this model.

Model $B$ has the characteristics of a cognitive development program, while goals and specific objectives which are not provided by model $A$ are allocated for each subject area in this model. Based on the set goals and objectives, program contents are then defined, that is, the thematic structure that determines their scope and order, as well as the proper activities for their realization. In this model, a new approach is observed which is reflected in the way of presenting content, since the goals and learning objectives are crucial in this model, which is in accordance with contemporary concepts of curricula which are based on formulating the education goals which are predetermined by the choice of appropriate content (Poljak, 1985, 38).

Goals, learning objectives, and the content linked to them which are further related to the field of PE do not differ significantly in model $A$ and $B$ and are divided into three thematic areas: physical development, development of perception, health improvement and hygiene. However, the thematic areas of early mathematics education differ significantly depending on the model - in model $A$ five thematic areas are given - perception and understanding of space and spatial relations; logical operations related to specific objects and phenomena; concept of geometry of plane-shapes and space-shapes; measurements and measures; temporal relations, while in model $B$ there are eight - positions; movement through space; comparison and evaluation; planes, lines, points; shapes; constructing sets; counting and sets; knowledge about time.

By comparing the goals, objectives and content given in the models, it can be seen that they do not differ significantly, except in how they are divided into thematic areas. From a mathematics point of view, the choice of thematic area and their corresponding content is very important since the contents studied within a thematic whole should represent a system of concepts concentrically distributed within it, that is, they should be chain-linked so that each subsequent concept can be understood by referring to those which preceded it in that sequence. Given the layout of thematic areas of early mathematics education and the concepts related to them, and taking into consideration the similarity between the goals of mathematics and PE within the thematic areas given in the models, model $B$ is better suited for their integration. One more reason to support this is the fact that the target activities within model $B$ have a certain pedagogical goal which should be achieved through specific objectives, while the target activities carried out based on model $A$ mostly resemble spontaneous game that is not sufficient for the proper development of the body, and this aspect of development must be paid special attention to. 
In the second step, we identified the related learning objectives that we observed through the objectives of the thematic areas within the PE curriculum (Table 1) and in relation to them, we identified the proper goals provided for the thematic areas of mathematics. Content linked with the specified related objectives is taught using total integration. The objectives of the thematic area of PE related to the development of perception are not listed in the table because they are related to all objectives of early mathematics education, that is, they develop during every activity that relates to the development of initial mathematical concepts. These goals relate, for example, to: acquiring a rich sensory experience, forming a flexible system of perceptions, developing perceptual abilities.

Table 1 Related objectives of math and PE in relation to thematic areas

\begin{tabular}{|c|c|}
\hline Physical Education objectives & Early Mathematics Education objectives \\
\hline Physical development & $\begin{array}{l}\text { Movement through space, } \\
\text { Position and knowledge about time }\end{array}$ \\
\hline $\begin{array}{l}\text { - Motor skills development, that is, } \\
\text { formation and strengthening to } \\
\text { learn the space around you } \\
\text { through movement which is } \\
\text { coordinated, graceful, balanced } \\
\text { and rhythmic; } \\
\text { - Mastering basic locomotor and } \\
\text { manipulative movement skills and } \\
\text { perfecting fine motor skills, } \\
\text { related to the development of } \\
\text { thinking and perception, precision, } \\
\text { orientation in space, concentration } \\
\text { and other skills necessary to } \\
\text { acquire graphical and technical } \\
\text { skills that writing depends on; } \\
\text { - Proper development of the } \\
\text { nervous system. }\end{array}$ & $\begin{array}{l}\text { Ability to: } \\
\text { - Identify direction in space in real life situations, move in the } \\
\text { three-dimensional space, (forward, backward, left, right, straight, } \\
\text { etc.) and combination of directions; } \\
\text { - Perceive space in relation to one's own body (right and left) and } \\
\text { the position of certain parts of the body, one against the other, as } \\
\text { well as the perception of the various positions of the body and } \\
\text { the position of objects; } \\
\text { - Perceive the relationship between various objects in space and } \\
\text { changing this relationship under different circumstances (inside, } \\
\text { outside, over, above, under, behind, next to, on, around, } \\
\text { between, etc.); } \\
\text { - Perceive relationships between objects (arranged according to a } \\
\text { certain rule - in a line, in a circle, in two rows, etc.) and } \\
\text { presenting them with a model, or graphically, or describing their } \\
\text { position with words); } \\
\text { - Arrange objects based on a certain (in line, in series by size or } \\
\text { any other feature, etc.); } \\
\text { - Predict where a thrown object will fall; } \\
\text { - Perceive how fast time passes based on rhythmic structures (fast, } \\
\text { slow, etc.) and objectify this time flow by linking time and } \\
\text { space. }\end{array}$ \\
\hline Health improvement and hygiene & $\begin{array}{l}\text { Comparison and evaluation, } \\
\text { Movement through space }\end{array}$ \\
\hline $\begin{array}{l}\text { - Developing health culture in order } \\
\text { to preserve and improve physical } \\
\text { and mental health (orientation and } \\
\text { getting around in nature, tracking } \\
\text { changes in weight, height and } \\
\text { physical abilities.). }\end{array}$ & $\begin{array}{l}\text { Ability to: } \\
\text { - Move in a three-dimensional space, (forward, backward, left, } \\
\text { right, straight, etc.) and combination of directions; } \\
\text { - Identify direction in space in real life situations; } \\
\text { - Understand and use, on a basic level, traditional units of measure } \\
\text { (thumb, hand, step...) and conventional units of measure (meter, } \\
\text { kilogram and litre). }\end{array}$ \\
\hline
\end{tabular}

Content linked to non-related goals can be integrated in different ways using some of the other three suggested types of integration. Moreover, if we look at these types of integration through the types of activities that are carried out within each of them, the 
total integration of unrelated goals would be applied to the activities envisaged for acquiring new knowledge from both areas, while Mathematics - Centred, Physical Assisted integration, and Physical - Centred, Mathematics - Assisted Integration would be used in cases where knowledge is acquired within the central subject area, while assisted areas help develop skills and habits.

\section{DESIGNING AN INTEGRATED ACTIVITY FOR MATH AND PHYSICAL EDUCATION}

Promoting moderate-intensity activity could provide benefits for cognitive mathematics engagement. Moreover, the results of numerous studies that dealt with issues of integrating mathematics and PE indicate that math \& sport performance (Fahiminezhad, Mozafari, Sabaghiyanrad, \& Esmaeili, 2012), movement-based learning across mathematics (Riley, Lubans, Holmes, Gore, \& Morgan, 2017), the use of kinaesthetic experiences associated with dance (Evangelopoulou, 2014) all improve students' math skills, critical thinking and creativity, as well as enhance the learning environment (Thompson \& Robertson, 2015), and child motivation. Socio-emotional and motor skills also had a positive effect on children's enjoyment and engagement without compromising the quality of learning (Riley et al., 2017).

When designing the activities, we were guided by the fact that content linked with related goals is studied through total integration, while other contents are studied using some of the other forms. In doing so, we made sure that when knowledge is gained within the core subject area, while assisted areas help develop skills and habits, one of the following forms is used: Mathematics - Centred, Physical - Assisted Integration, or Physical - Centred, Mathematics Assisted Integration.

The first step is to identify the main goal and then to specify the topic and sub-topic and the choice of content that will be studied. In accordance with the goal set, the learning objectives are formulated which are then linked if we deal with related goals, or are singled out as separate if we deal with non-related goals. In the second step, the activity of reviewing the essential questions is planned, and the development of a list of possible integrated activity outcomes also takes place. Moreover, some questions that should be taken into consideration are the following: What concepts do we want children to develop?, What do we want children to be able to do?, In what ways will we have fostered children's thinking?, What interdisciplinary connections will we have made?, What connections will the children have made with "daily life experiences"?, How will children demonstrate their learning? etc. And lastly, in the third step, integrated project and discipline-specific activity are generated. The text below will provide examples for the three forms of integration.

Total Integration of Related Learning Objectives (TIRLO)

Theme: Movement and Orientation in Space: left, right.

Learning objectives: Children should be able to: observe the directions of movement through space in their own motion and the movement of others - left, right; perceive space in relation to their own body - differentiating between the right and left hand and distinguishing where the right and left is in relation to one's own body; develop motor skills, that is, the ability to master the space through movement in it - coordination, balance, rhythm; perfect fine motor skills - voluntary movement, coordination, rhythm, accuracy, tempo, orientation in space; verbal express themselves using the terms left and right. 
Introduction: The game We are going on a lion hunt contains elements of drama where children move through space, developing, in the first place, motor skills, and in addition to it, psychophysical abilities, balance and coordination of movements and some muscle groups - they walk, jump, raise their right and left hand and show the right or left side in relation to their own body, they stomp their feet developing balance and coordination of movement, they imitate swimming and turn their heads to the left and right which helps them to develop shoulder and back muscles, they exhale - strengthening respiratory muscles.

Activity: The game begins with children standing in a circle around the teacher while he/she is explaining to them that they are going into a great imaginary adventure through the forest with the aim of catching a lion. They then stand in line behind the teacher who is moving around the room acting out the lines from the game and in accordance with them making certain moves. Children move around the room following the teacher and make the same movements as the teacher during the game We are going on a lion hunt.

We are going on a lion hunt and we came across a biiiig forest, we can't go right, we can't go left, we have to go right (they show the sides with hands). We walk through the forest crack, crack, crack, left - right, left - right foot (they imitate the cracking sound by stomping their feet first with their left and then the right foot). A twig is caught on our right leg, quickly take the twig off the right leg (they show their right leg and shake the imaginary twig from it). We keep on walking through the forest crack, crack, crack (they mimic the cracking sound by stomping their feet first with their left and then the right foot). We are going on a lion hunt and we came across a biiiig pond, we can't go right, we can't go left, we have to go right (they show the sides with hands and move in the specific direction). We walk through the pond splash, splash, splash... (they stomp their feet first with their left and then the right foot). Look buddies, there are frogs in the pond on the right, they are jumping along with us (children jump). We keep on walking through the pond, splash, splash, splash... (they stomp their feet first with their left and then the right foot just like the teacher). We keep on walking when suddenly there are rabbits in front of us, we explain to them to turn right (they show the right side) so that we can continue our trip. We are going on a lion hunt and we came across a biiiig fire, we can't go right, we can't go left, we have to go right (they show the sides with hands and move in the specific direction). We walk through the fire Hoooo woooo! Hoooo woooo! Hoooo woooo! (Blow left and then right looking at what their teacher is doing).

Look buddies, firefighters are coming and they are putting out the fire on the left (show the left side), we pass and carry on. We are on a lion hunt and we came across a biiiig lake, we can't go right, we can't go left, we have to go right (they show the sides with hands and move in the specific direction). We swim, right-left, right-left, right-left (they mimic swimming movements). Let's change our style, left-right, left-right, left-right, (they mimic swimming movements), splash, splash, splash. Buddies, look right, the fish are swimming with us. The fish have left but we carry on swimming (they mimic swimming movements), splash, splash, splash. We are out of the pond and we carry on walking. We are walking through the forest, when suddenly a flock of birds flew by, some went right, some went left (they look right, and then left). We arrive at the end of the road, we look left, there is nothing, we look right and see the cave. We enter the cave, we light a lantern and see the lion (scream). Quick, back through the forest! Splash, splash, splash (they mimic swimming), Hoooo woooo! Hoooo woooo! Hoooo woooo! (they blow left then right several times). Splash, splash, splash... (they stomp their feet first with their left and then the right foot). Crack, crack, crack, crack, crack crack (they mimic the cracking sound by stomping their feet). We've arrived at the kindergarten, we enter the room, turn the lights on, and we are not scared of the lion at all! 


\section{Total Integration of Unrelated Learning Objectives (TIULO)}

Themes: Developing concepts of size relations: longer-shorter; Developing control of large muscles: running, jumping, balancing, catching.

Mathematics learning objectives: Children should be able to: identify and distinguish between length and the other dimensions; to compare objects by length and based on that determine relations such as longer-shorter; name relations longer-shorter; do seriation of objects by length.

Physical learning objectives: Children should be able to: develop psychophysical abilities - speed, agility, and flexibility; develop balance in dynamic body positions; strengthen respiratory muscles through rhythmic breathing and increasing lung capacity.

Introduction: The main orientation when learning about size relations is the emphasis on two mutually opposite relations. Furthermore, it is necessary for children to do the seriation of objects according to specific spatial dimensions. Didactic and other material used when learning these dimensions of objects are chosen so that the differences in dimension size in relation to which we observe mutually opposite relations is considerably asserted, while the other dimensions are the same. The reason for this is that children could easily notice and distinguish the specific (essential) characteristic of the objects that we observe, and which we want to master (in our case, length). Comparing the objects based on their length is done by placing them next to each other, but in such a way that their ends are aligned on one side. Through the game Cat and mice children participate in developmentally appropriate gross motor activities along with natural forms of movement with elements of athletics: running, jumping, balancing, catching.

Activity: The teacher explains to the children the rules of the game Cat and mice. All the children will be mice, except for one, to be selected with a counting rhyme. The selected child will represent the cat. There will be a rope in the shape of a circle in the middle of the room that will represent the mouse hole. Every child will attach a tail of cloth strips different in length on the belt. At the beginning of the game, the children mice hide in the hole (they stand inside the circle). When the cat falls asleep, the mice are safe and get out of the hole to play or look for food. The cat suddenly wakes up and starts chasing the mice. Whoever is caught, the cat tears his/her tail off and that child leaves the game. The mice that manage to get back into the hole while they are being chased by the cat are safe and the cat cannot chase them and catch them while they are in the hole. The game continues until there is only one free mouse that wins the game or until the time the game runs out - then the winners are those mice that the cat did not catch. Children compare the length of the tails of those mice caught by the cat. The teacher chooses couples of children who compare their tails and identify the relationship longer-shorter. The teacher then asks the children to do seriation by length, that is, to arrange them from the shortest to the longest and vice versa. They do this by firstly comparing two tails, and then add another one comparing its length to the previous ones... keep doing this until all the tails are arranged.

\section{Physical - Centred, Mathematics - Assisted Integration (TPCMAI)}

Theme: Healthy and unhealthy food

Subtheme: Comparing sets and developing set relations: more, less, equal to

Physical learning objectives: Children should be able to: identify healthy and unhealthy foods, gain knowledge about proper nutrition, be motivated to eat healthy food. 
Mathematics learning objectives: Children should be able to: identify equal and unequal sets; gain knowledge about concepts of set relations: equal to, less and more; verbally express themselves using terms: equal to, less and more.

Introduction: Children are introduced to healthy and unhealthy foods through a specific conversation. At the same time, by using sets of healthy and unhealthy foods in different ways, children refresh the knowledge gained about equal sets and set relations such as equal to, more, less.

Activity: Assess prior knowledge by asking the children who ate something healthy today. Show children various plastic healthy and unhealthy foods and invite them to come up one by one and identify if they think the food they selected is healthy or unhealthy. On a whiteboard or chalkboard, make two columns. One column should be labelled healthy and one column should be labelled unhealthy. Then, call the children up one by one to select different foods and decide whether they are healthy or unhealthy. When they choose one, discuss with the children why they think that is correct or incorrect. Then, help the children tape them to the right side of the chart. Continue until each child had a turn or until you have used up all of the pictures. Then ask the children to connect (associate) the elements of the set containing healthy food with the elements of the set containing unhealthy food, and vice versa, and then through this association operation decide whether these sets have an equal or unequal number of elements. Children should do that using appropriate wording. We ask the children to Create a Healthy Lunch! and then ask them to break the given set into different subsets (such as, fruit set, vegetable set), to name them and finally to assign relations to them: more, less, or equal to.

\section{CONCLUSION}

Mathematical concepts are abstract concepts, but that does not mean that they should be studied separately from real life. We start with real objects, and mathematical concepts are the properties of those very objects that do not exist separately from those objects. Therefore, they should be observed as abstract and studied as such. However, it is more difficult to study abstract concepts than concepts that are not a mental creation, but rather physical or material. That is why one of the common misconceptions is that Young children are not ready for mathematics education, which underestimates children's mathematical abilities in the early years. The results of many studies speak in favour of children having a wider range of mathematical abilities than previously thought, as well as that children's learning begins long before they enter school. Since children of a preschool age find it harder to learn isolated subject areas, content integration is a good basis for development, not only of mathematical but also of concepts from other subject areas.

Mathematics and PE are subject areas that children do not immediately associate as having common ground and yet there are some clear fundamental links that underpin these two areas of learning. When presented alongside each other, the uniqueness of both subjects can be very powerful in offering children a holistic learning experience that can also aid understanding in both areas. PE can enable children to learn about, explore and use to apply key mathematical concepts and language. On the other hand, developing mathematical concepts can help children to value and participate in regular and habitual physical activity throughout their lives. Therefore, the integration of these subject areas is important for the overall development of a preschool aged child, that is, for the development of physical, social, emotional and cognitive skills as well as knowledge, understanding and attitudes. 
Integration can be facilitated in many ways. Therefore, the first task of the educator is the proper choice of models of integration. It starts from the aims and learning objectives of preschool mathematics and PE which should be realized using the appropriate model of integration. For this reason, we have outlined the related goals and learning objectives that are realized with the use of total integration. In this regard, the objectives of PE related to the development of perception can be fully integrated with all objectives related to mastering mathematical concepts since mathematical thinking of preschool children takes place in the sensory-experiential stage of the cognitive process, that is, relying on observations. When it comes to the other objectives, most matches were found among those related to physical development and movement through space and position. Nonrelated objectives can be realized using some of the other types of integration by combining goals that are not related, or by separating those that will be seen as primary ones, that is, core ones from those which will be seen as assisting in that integration.

In the paper we have presented only some of the possibilities regarding the usage of different types of integration of preschool mathematics and PE. Their range and effects are conditioned by the theme and ability of the educator to create a variety of ways to engage children in learning which will give the children a sense of purpose for their work. Besides the considered possibilities offered by the discussed types of integration, it would be necessary to consider some other types of integration that can be applied with the contents of these subject areas, such as the integration model where tasks from one subject area are central while others are immersed, which would further more thoroughly explain and support the usage of the primary subject area content in the secondary subject area. PE content can provide children with 'real life' opportunities to explore, develop and apply their mathematical skills, and understanding which also supports curiosity and questioning. Enlightening their characteristics in the context of early mathematics and PE would contribute to integrating the aims of preschool mathematics and PE, but is also a challenge for everyone who works in preschool education.

\section{REFERENCES}

Claessens, A., Duncan, G., \& Engel, M. (2009). Kindergarten skills and fifth-grade achievement: Evidence from the ECLS-K. Economics of Education Review, 28, 415-427.

Clements, D.H., \& Sarama, J. (2007/2013). Building blocks, Volumes 1 and 2. Columbus, OH, USA: McGrawHill Education.

Clements, D.H., \& Sarama, J. (2018). Myths of early math. Education Sciences, 8(2), 71

Cvejić, D., \& Buišić, S. (2012). Integrisanje nastave u cilju povećanja fizičke aktivnosti dece (Integrating teaching in order to increase the physical activity of children). Nastava $i$ vaspitanje, 61(4), 754-765.

Ćebić, M. (2009). Početno matematičko obrazovanje predškolske dece (The initial mathematics education of preschool children). Belgrade: Teachers Training Faculty, University of Belgrade. In Serbian

Do and discover, fun activities to develop physical skills in the early years (2008, January 14). Bridgend, southern Wales, UK: Bridgend County Borough Council. Retrieved March 19, 2018 from the World Wide Web: http://learning.gov.wales/docs/learningwales/publications/130212do-and-discoveren.pdf

Ericsson, I., \& Karlsson, M. (2014). Motor skills and school performance in children with daily physical education in school-A 9-year intervention study. Scandinavian Journal of Medicine \& Science in Sports, 24(2), 273-278.

Evangelopoulou, P. (2014). A case study on Maths Dance: The impact of integrating dance and movement in maths teaching and learning in preschool and primary school settings. Master's Degree Studies in International and Comparative Education, Institute of International Education Department of Education, Stockholm University. 
Fahiminezhad, A., Mozafari, S., Sabaghiyanrad, L., \& Esmaeili, M. (2012). The effect of traditional and integration methods of teaching of the amount of learning math and sport performance of first grade of elementary students. European Journal of Experimental Biology, 2(5), 1646-1653.

Fogarty, R. (1991). The mindful school: How to integrate the curriculum. Palatine, IL: Skylight Publishing.

Fogarty, R.J., \& Stoehr, J. (2008). Integrating curricula with multiple intelligences: Teams, themes, and threads. Corwin Press.

Gao, Z., Hannan, P., Xiang, P., Stodden, D.F., \& Valdez, V.E. (2013). Video game-based exercise, Latino children's physical health, and academic achievement. American Journal of Preventive Medicine, 44(3, Suppl. 3), 240-246.

Ginsburg, H.P., Greenes, C., \& Balfanz, R. (2003). Big math for little kids. Parsippany, NJ, USA: Dale Seymour.

Griffin, S., Clements, D.H., \& Sarama, J. (2007). Number worlds/building block: A prevention/intervention program: Teacher edition level B. Columbus, OH, USA: SRA/McGraw-Hill.

Grube, D., \& Beaudet, B. (2005). Physical education and the ABCs: An interdisciplinary approach. Strategies, 18(6), 11-14.

Haydn-Davies, D., Kaitell, E., Randall, V., \& Shaughnessy, J. (2014, May 12). Maths and physical education in primary education 'More than just counting beanbags'?. UK: National Centre for Excellence in the Teaching of Mathematics (NCETM). Retrieved February 05, 2018 from the World Wide Web: https://www.ncetm.org.uk/files/18341027/Maths+and+PE.pdf

Hollar, D., Messiah, S. E., Lopez-Mitnik, G., Hollar, T. L., Almon, M., \& Agatston, A.S. (2010). Effect of a two-year obesity prevention intervention on percentile changes in body mass index and academic performance in low-income elementary school children. American Journal of Public Health, 100(4), 646.

Humphreys, A., Post, T., \& Ellis, A. (1981). Interdisciplinary methods: A thematic approach. Santa Monica, CA: Goodyear Publishing Company.

Jacobs, H.H. (1989). Design Options for an Integrated Curriculum. In H.H. Jacobs (Ed.), Interdisciplinary curriculum Design and implementation. (pp. 13-24). Alexandria, VA: Association for Supervision and Curriculum Development.

Kamenov, E. (1987). Predškolska pedagogija, knjiga 1 (Preschool Pedagogy, Book I). Belgrade: Zavod za udžbenike i nastavna sredstva. In Serbian

Kindergarten integrated curriculum document (2008). Prince Edward Island: Education and early childhood development. Retrieved April 15, 2018 from: http://www.gov.pe.ca/photos/original/k_doc.pdf

Kiray, S.A. (2012). The new model for the integration of science and mathematics: The balance model. Energy Education Science and Technology Part B: Social and Educational Studies, 4(3), 1181-1196.

Krajewski, K., \& Schneider, W. (2009). Early development of quantity to number-word linkage as a precursor of mathematical school achievement and mathematical difficulties: Findings from a four-year longitudinal study. Learning and Instruction, 19, 513-526.

Lake, K. (1994). Integrated curriculum, School improvement research series. Portland: Northwest Regional Education Laboratory's.

Lee, J.S., \& Ginsburg, H.P. (2009). Early childhood teachers' misconceptions about mathematics education for young children in the United States. Australasian Journal of Early Childhood, 34(4), 37-45.

Maksimović, J., \& Osmanović, J. (2018). Physical education teachers as reflective practitioners and action researchers in their work. Facta Universitatis Series Physical Education and Sport, 375-386.

Malinović-Jovanović, N., \& Milojević, M. (2013). Priča i motivacija pri izgrađivanju i formiranju početnih matematičkih pojmova (Story and motivation in developing and forming initial mathematical concepts). In S. Denić (Ed.), Književnost za decu i njena uloga u vaspitanju i obrazovanju dece školskog uzrasta (Literature for children and its role in the education of primary school children). (pp. 176-188). Vranje: Teachers Training Faculty in Vranje, University of Niš. In Serbian

Maričić, S., Stakić, M., \& Malinović-Jovanović, N. (2018). The role of literary content for children in preschool mathematics education. EURASIA Journal of Mathematics, Science and Technology Education, 14(2), 631-642.

Momčilović, Z., \& Momčilović, V. (2016). Attitudes of the students of the Teacher-Training Faculty in Vranje towards physical education. Facta Universitatis Series Physical Education and Sport, 14 (3), 455-462.

National Association for the Education of Young Children-NAEYC \& National Council of Teachers of Mathematics-NCTM (2002). Position statement. Early childhood mathematics: Promoting good beginnings. Retrieved October 23, 2016 from the World Wide Web: https://www.naeyc.org/files/naeyc/file/ positions/psmath.pdf

Opšte osnove predškolskog programa (Preschool Curriculum Framework). "Sl. glasnik RS - Prosvetni glasnik", № 14/2006. In Serbian

Piaget, J., \& Inhelder, B. (1978). Intelektualni razvoj deteta (Intellectual development of the child). Belgrade: Zavod za udžbenike i nastavna sredstva. In Serbian 
Piaget, J., \& Inhelder, B. (1990). Psihologija deteta (The psychology of the child). Sremski Karlovci: Izdavačka knjižarnica Zorana Stojanovića; Novi Sad: Dobra vest. In Serbian

Poljak, V. (1985). Didaktika (Didactics). Zagreb: Školska knjiga.

Riley, N., Lubans, D., Holmes, K., Gore, J., \& Morgan, P. (2017). Movement-based mathematics: enjoyment and engagement without compromising learning through the easy minds program. EURASIA Journal of Mathematics Science and Technology Education, 13(6), 1653-1673.

Riley, N., Lubans, D.R., Morgan, P.J., \& Young, M. (2014). Outcomes and process evaluation of a programme integrating physical activity into the primary school mathematics curriculum: The EASY Minds pilot randomized controlled trial. Journal of Science and Medicine in Sport, 18(6), 656-661.

Sarama, J., Brenneman, K., Clements, D.H. (2017). Interdisciplinary teaching across multiple domains: The C4L (Connect4Learning) curriculum. In L.B. Bailey (Ed.) Implementing a standards-based curriculum in the early childhood classroom. (pp. 13-65). New York, NY: Taylor \& Francis.

Seo, K.H., \& Ginsburg, H.P. (2004). What is developmentally appropriate in early childhood mathematics education? In D.H. Clements, J., Sarama, \& A.M. DiBiase (Eds.), Engaging young children in mathematics: Standards for early childhood mathematics education. (pp. 91-104). Mahwah, NJ: Eribaum.

Sibley, B.A., \& Etnier, J.L. (2003). The relationship between physical activity and cognition in children: a meta-analysis. Pediatric Exercise Science, 15(3), 243-256.

Stevens, T.A., To, Y., Stevenson, S.J., \& Lochbaum, M.R (2008). The importance of physical activity and physical education in the prediction of academic achievement. Journal of Sport Behavior, 31(4), 368-388.

Thompson, S.D., \& Robertson, J.L. (2015). The Effects of integrating mathematics into the physical education setting. Masters of Arts in Education Action Research Papers. Retrieved February 11, 2018 from Sophia, the St. Catherine University repository website: https://sophia.stkate.edu/maed/101

Vilotijević, M., \& Vilotijević, N. (2008). Inovacije u nastavi (Innovation in Teaching). Vranje: Teachers Training Faculty in Vranje, University of Niš. In Serbian

Vygotsky, L.S. (1978). Mind in society: The development of higher psychological processes. Cambridge, MA: Harvard University Press.

\section{MOGUĆI MODELI INTEGRACIJE PREDŠKOLSKOG MATEMATIČKOG OBRAZOVANJA I FIZIČKOG VASPITANJA}

Osnovni cilj u radu bio je da se na osnovu karakteristika mišljenja dece predškolskog uzrasta, ciljeva i zadataka predškolskog obrazovanja i specifičnosti predškolskog matematičkog obrazovanja $i$ fizičkog vaspitanja, predlože mogući modeli integracije ovih predmetnih oblasti. Istraženo je "zašto je potrebno integrisati sadržaje ovih predmetnih oblasti”, kao i različiti modeli integracije, izdvojeni su srodni ciljevi $i$ zadaci $i$ odgovarajući oblici integracije pogodni za povezivanje sadržaja ovih predmetnih oblasti. Kroz totalnu integraciju srodnih ciljeva, kao i posmatrajući matematiku kroz fizičko vaspitanje i fizičko vaspitanje kroz matematiku, na konkretnim primerima date su različite mogućnosti integrisanja ovih sadržaja $i$ odgovarajuća uputstva za njihovo kreiranje. Doprinos integracije sadržaja ovih predmetnih oblasti, između ostalog, ogleda se i u tome što fizičko vaspitanje pruža deci mogućnosti da apstraktne matematičke pojmove vide iz drugog ugla, uče, istražuju $i$ primenjuju ih kroz oblast fizičkog vaspitanja.

Ključne reči: predškolsko matematičko obrazovanje, predškolsko fizičko vaspitanje, karakteristike kognitivnog razvoja, integracija, modeli integracije 